\title{
Extent of Involvement of Women in Dairy Farming Activities in Oyo State, Nigeria
}

\author{
Adebisi Gbadebo Luqman ${ }^{1}$, Popoola Moshood Abiola ${ }^{1}$, Olaniyi Taiwo Anne ${ }^{1}$, Aladegbaye Mercy Ifeoluwa ${ }^{1}$, \\ Aigbe Festus Odunayo ${ }^{1}$, Owoade Solomon Adebayo ${ }^{1}$, Soyewo Imoleayo Enitan ${ }^{1} \&$ Ayodele Victor Adewale ${ }^{1}$ \\ ${ }^{1}$ Federal College of Animal Health and Production Technology, Moor Plantation, Ibadan, Nigeria \\ Correspondence: Popoola Moshood Abiola, Federal College of Animal Health and Production Technology, Moor \\ Plantation, Ibadan, Nigeria. E-mail: popoola_abiola@yahoo.com
}

Received: April 21, 2020 Accepted: April 28, 2020 Online Published: May 5, 2020

\begin{abstract}
The study was conducted to evaluate extent of involvement of women in dairy production in Oyo state. Two stage sampling procedure was used for the study with 112 questionnaires administered through a scheduled interview to obtain information from the respondents. Data were collected on socio-economic characteristics, dairy production enterprise of the respondents and their extent of involvement in dairy production activities. Data collected were subjected to descriptive statistics and regression analysis. The result of the study showed that most of the respondents were older than 25 years; they were Muslims, married, had no formal education and had 5-7 members as household size. The study further revealed that women were more involved in marketing activities (93.2\%) and processing activities $(92.4 \%)$ while they had low involvement in daily management activities and health activities of dairy cattle. The overall involvement index of the respondents show that most $(91.1 \%)$ of the respondents had high involvement in dairy production activities. Based on the result of the study, it was concluded that most of the respondents were highly involved in processing and marketing of dairy products; they were not involved in daily management and health activities of dairy cattle. It was further concluded that the overall involvement index of the respondents was high in dairy production enterprise. Income and secondary occupation were significant factors influencing extent of involvement in dairy production enterprise.
\end{abstract}

Keywords: activities, cattle, dairy, enterprises, involvement, women

\section{Introduction}

Nigeria is one of the leading countries in cattle production in sub-Saharan Africa, the country had over 14.73 million cattle consisting of 1.47 million milking cows and 13.26 million beef cattle (Tibi and Aphunu, 2010). Cattle production sector is performing a vital role in the economies of many developing countries where it is a source of animal protein (food), income, employment and foreign exchange. For small income producers, it provides draught power and organic fertilizer for crop production; serves as store of wealth and means of transportation as well (Garcia et al., 2003). Cattle accounted for about $77 \%$ of the milk produced and so dairying is considered to have the potential to bring steady income. The importance of milk and milk products for the physical and nutritional benefit is universally recognized (Sethi, 2013). Dairy sector is performing a vital role in the economies of many developing countries where it is a source of animal protein, income, employment and foreign exchange.

Dairy have been described as an asset that women can own more easily and that have the potential to contribute to a reduction in the gender asset gap within households (Kristjanson et al., 2010). It is often easier for many women in developing countries to acquire animals, whether through inheritance, markets or collective action processes, than it is for them to purchase land or other physical assets or to control other financial assets (Rubin and Missokia, 2006). Various micro level studies highlight women's significant role in dairy production (Khin, 2005; Savitha, 2004). It is a proven fact that the role of farm women is worthy enough in comparison with their male counterparts. Women are the prime decision makers in dairy production activities such as utilization of milk, care of pregnant animal and calves, bringing of fodder and feeding concentrates (Veeranna and Singh, 2004).

Gender issue shape the totality of production, distribution and consumption within an economy but have often been overlooked in a value chain development, from production, processing and marketing (Gour, 2002). According to Wadear et al., (2003), lots of factors hold women back and needs to be reversed such as lack of education, unequal property rights, exclusion in decision making and limited control over resources. In Nigeria, 
the pastoralists who are majorly Fulani do not reckon with decision of women in cattle production, this gender gap has limited roles and contribution of women in dairy value chain. An understanding of role of women dairy farmers, and importance is a prerequisite to devising policies to improve productivity and socio-economic development. Thus, this study was designed to evaluate the involvement of women in dairy farming activities in Oyo state, Nigeria.

\section{Methods}

The study was conducted in Oyo State; it is located in the South-West geopolitical zone of Nigeria. It consists of 33 Local Government Areas (LGAs). The State covers a land area of 28,454 square kilometers with a population of 5.6 million people NPC, (2006) with climatic conditions that favour agriculture. The wet season is from April to October, with the mean temperature of $27^{\circ} \mathrm{C}$. The dry season is between November and March. The mean annual rainfall is $1,194 \mathrm{~mm}$ in the North and $1,264 \mathrm{~mm}$ in the South. Within Oyo state, the Zebu cattle (White Fulani and other Zebu breeds) are herded in the lowlands, amidst land progressively used for crop production. The major crops grown in the state include cassava, maize, yam, sorghum, cocoa, cocoyam, melon, peppers, soybean and okro; major livestock reared in the state include; cattle, sheep, goat and poultry.

A two-stage sampling procedure was adopted for this study. The first stage involved purposive selection of nine local government areas (LGAs) where dairy farmers were predominant in the state. The areas are Ido, Iseyin, Lagelu, Saki, East, Saki West, Ibarapa East, Oyo West Itesiwaju, and Ogbomosho North. List of these farmers was generated in each of these LGA from their Associations. The second stage involved random selection of at least 10 members who are women from the list in each of the LGA to give 112 women as respondents. A wellstructured interview schedule was used to obtain information from these respondents. Data were collected on socio-economic characteristics of the respondents, their dairy cattle production enterprises and their extent of involvement in dairy production. The extent of involvement of respondents was obtained by measuring their involvement in dairy activities which are divided into four aspect viz; management, health, processing and marketing activities. This extent of involvement was grouped on 3 points scale as Regularly, Occasionally and Never and scores were given as 3, 2 and 1 respectively. The aggregate involvement score of each respondent was obtained by adding the respective score for each item. Based on the total score obtained by the respondents, involvement index was estimated by using the following formula according to Sowjanya, (2014):

\section{Involvement index $==\frac{\text { obatained score }}{\text { maximum obtained scores }} \times 100$}

Based on the responses of the respondents, frequencies and percentages was calculated. Maximum score obtained by respondents from the index was indicated as higher or lower participation in different activities of dairy which was used to categorize respondents' involvement in the dairy production activities as high or low (Sowjanya, 2014).

Data were subjected to descriptive statistics (mean, frequency and percentage) and regression analysis using SPSS (V.21).

\section{Results}

Table 1 shows the socio economic characteristics of the respondents. Result revealed that most $(40.2 \%)$ of the respondents were older than 25 years, followed by those within age range of $16-20$ years $(10.7 \%)$ and the least $(2.7 \%)$ were those who were less than 5 years old. The mean age of the respondents was 25.7 years. Majority of the respondents were married $(72.3 \% \%)$; this is expected with result obtained for their age. Married respondents are likely to be under pressure to produce more, not only for family consumption but also for sale. All the respondents were Muslims with most (73.2\%) having no formal education, $25 \%$ of them had primary education, few (1.8\%) of the respondents had secondary education. The result of household size of respondents showed that majority of the respondents had household size between 5-7 members (38.4\%), 27.7\% had household size of between $8-10$ members, while $9.8 \%$ had household size of between $11-13$ members as the least. The mean household size was 9. The result further revealed that half $(50 \%)$ of the respondents earned more than N18,000 $\mathrm{N} 22,000$ as income followed by those who earned (34.8\%) earned less than N18000,(7.1\%) earned above N32000, $(5.4 \%)$ and $(2.7 \%)$ earned between N23000-N27000 and N28000-N32000. 
Table 1. Socio economic characteristics of respondents

\begin{tabular}{|c|c|c|c|}
\hline Variables & Frequency & Percentage & Mean \\
\hline \multicolumn{4}{|l|}{ Age (years) } \\
\hline 5 & 3 & 2.7 & \\
\hline $5-10$ & 6 & 5.4 & \\
\hline $11-15$ & 11 & 9.8 & \\
\hline $16-20$ & 12 & 10.7 & \\
\hline $21-25$ & 35 & 31.2 & \\
\hline$>25$ & 45 & 40.2 & 25.7 \\
\hline \multicolumn{4}{|l|}{ Marital status } \\
\hline Single & 30 & 26.8 & \\
\hline Married & 81 & 72.3 & \\
\hline Widowed & 1 & 0.9 & \\
\hline \multicolumn{4}{|l|}{ Religion } \\
\hline Islam & 112 & 100.0 & \\
\hline \multicolumn{4}{|l|}{ Educational status } \\
\hline Primary & 28 & 25.0 & \\
\hline Secondary & 2 & 1.8 & \\
\hline No formal Education & 82 & 73.2 & \\
\hline \multicolumn{4}{|l|}{ Household size } \\
\hline$<5$ & 27 & 24.1 & \\
\hline $5-7$ & 43 & 38.4 & 9 \\
\hline $8-10$ & 31 & 27.7 & \\
\hline $11-13$ & 11 & 9.8 & \\
\hline \multicolumn{4}{|l|}{ Monthly Income } \\
\hline$<18,000$ & 39 & 34.8 & \\
\hline $18,000-22,000$ & 56 & 50.0 & \\
\hline $22,001-27,000$ & 6 & 5.4 & $21,163.31$ \\
\hline $27,001-32,000$ & 3 & 2.7 & \\
\hline$>32,000$ & 8 & 7.1 & \\
\hline
\end{tabular}

Result for dairy cattle production characteristics of the respondents is presented in Table 2 . The result revealed that majority (23.2\%) of the respondents had $9-12$ years of dairy production experience, $21.4 \%$ had less than 5 years' experience, $16.1 \%$ had 5-8 years and $17-29$ years of experience respectively, $14.3 \%$ had $>21$ years' experience and $8.9 \%$ had $13-16$ years' experience. The result also revealed that $25.0 \%$ of the respondent had more than 50 herds of cattle, $21.4 \%$ had $31-40$ herds of cattle, $20.5 \%$ had herds of $41-50$ cattle, $17.9 \%$ had $21-30$ herd of cattle, $11.6 \%$ had $10-20$ herd of cattle, while the least was $3.6 \%$ of the respondents with less than 10 herds of cattle. More than half of the respondents got their cattle through inheritance $(75.0 \%)$, some $(23.3 \%)$ got their cattle through gift and few $(0.9 \%)$ of the respondents got through contracts. Most of the respondents $(99.1 \%)$ possess White Fulani cattle while few ( $0.9 \%$ ) possess Red Bororo breed. Result further revealed that respondents possessed other livestock species like sheep (26.8\%); 25.0\% possessed chicken and sheep, $(15.2 \%)$ possessed chicken, $8.9 \%$ possessed chicken with goat, $7.1 \%$ possessed chicken and guinea fowl, $6.2 \%$ possessed chicken and guinea fowl $6.2 \%$, and $1.8 \%$ possessed sheep and goat. Furthermore, major purpose of cattle production of most of the respondents $(64.3 \%)$ was for milk production.

Table 2. Cattle production enterprise for daily respondents

\begin{tabular}{llll}
\hline Variables & Frequency & Percentage & Mean \\
\hline Years of experience & & & \\
$<5$ & 24 & 21.4 & \\
$5-8$ & 18 & 16.1 & \\
$9-12$ & 26 & 23.2 & \\
$13-16$ & 10 & 8.9 & \\
$17-20$ & 18 & 16.1 &
\end{tabular}




\begin{tabular}{|c|c|c|c|}
\hline$>20$ & 16 & 14.3 & \\
\hline \multicolumn{4}{|l|}{ Herd size } \\
\hline$<10$ & 4 & 3.6 & \\
\hline $10-20$ & 13 & 11.6 & \\
\hline $21-30$ & 20 & 17.9 & 50 \\
\hline $31-40$ & 24 & 21.4 & \\
\hline $41-50$ & 23 & 20.5 & \\
\hline$>50$ & 28 & 25.0 & \\
\hline \multicolumn{4}{|l|}{ Breeds of cattle } \\
\hline Red Bororo & 1 & 0.9 & \\
\hline White Fulani & 111 & 99.1 & \\
\hline \multicolumn{4}{|l|}{ Sources of cattle } \\
\hline Purchased & 1 & 0.9 & \\
\hline Gift & 26 & 23.2 & \\
\hline Inheritance & 84 & 75.0 & \\
\hline Contract & 1 & 0.9 & \\
\hline \multicolumn{4}{|l|}{ Other livestock species raised } \\
\hline Chicken & 17 & 15 & \\
\hline Goat & 8 & 7.1 & \\
\hline Sheep & 32 & 28.6 & \\
\hline Chicken and goat & 10 & 8.9 & \\
\hline Chicken and guinea fowl & 8 & 7.1 & \\
\hline Chicken and sheep & 28 & 25.0 & \\
\hline Goat and guinea fowl & 7 & 6.2 & \\
\hline Goat and sheep & 2 & 1.8 & \\
\hline \multicolumn{4}{|l|}{ Purposes of cattle production } \\
\hline Status quo & 6 & 5.4 & \\
\hline Status quo and cultural purposes & 2 & 1.8 & \\
\hline Ceremonies & 1 & 0.9 & \\
\hline Milk and meat production & 19 & 17.0 & \\
\hline Milk production & 72 & 64.3 & \\
\hline Milk production and cultural purposes & 6 & 5.4 & \\
\hline Milk production, status quo and cultural purposes & 6 & 5.4 & \\
\hline
\end{tabular}

The result in Table 3 shows the extent of involvement of respondents in dairy production. For daily management activities, the result revealed that the respondents were not regularly involved in daily management activities and were occasionally involved in cleaning of cattle (51.8\%), cleaning the animal shed (58.\%), washing of pen (54.5\%). However respondents never involved in taking animals for grazing $(95.5 \%)$, feeding and giving of water to animals $(53.6 \%)$, fodder and feed storage $(100 \%)$, preparation of feed and feed concentrates $(100 \%)$, construction of animal shed (62.5\%), disposal of animal wastes (79.5\%) and maintaining farm and dairy records $(95.5 \%)$ with the Involvement index of $8.24 \%$ which implies that there was low involvement of respondents in daily management activities of the dairy cattle. It was also revealed in the result that majority of the respondents regularly involved in processing of milk $(99.1 \%)$ and milking $(100 \%)$ with the involvement index measured to be $92.41 \%$, this is an indication that respondents were highly involved in milk processing activities. Furthermore, most of the respondents never involved in vaccination/medication (64.3\%), care of new born (52.7\%), care of sick animals (50.9\%), taking calves for dehorning (96.4\%), care of pregnant animal $(60.7 \%)$. According to the result, involvement index of respondents for health care activities was $10.41 \%$ which implies they have low involvement in health care activities. The result further revealed that all the respondents regularly involved in selling of milk $(100 \%)$ while majority never involved in selling $(97.3 \%)$ and purchasing of animals $(99.1 \%)$. The involvement index of the respondents for marketing activities was $93.24 \%$, which implies that there was high level involvement of respondents in marketing activities in dairy production. 
Table 3. Extent involvement of women in dairy production activities

\begin{tabular}{|c|c|c|c|}
\hline Variables & Regularly (\%) & Occasionally (\%) & Never $(\%)$ \\
\hline \multicolumn{4}{|l|}{ Daily Management Activities } \\
\hline Cleaning of animal & - & $58(51.8)$ & $54(48.25)$ \\
\hline Cleaning of animal shed & - & $65(58.0)$ & $47(42.0)$ \\
\hline Taking animal for grazing & - & $5(4.5)$ & $107(96.5)$ \\
\hline Feeding and provision of water for cattle & - & $52(46.4)$ & $60(53.6)$ \\
\hline Fodder and feed storage & - & - & $112(100)$ \\
\hline Preparation of feed concentrates & - & - & $112(100)$ \\
\hline Washing of pen & - & $61(54.5)$ & $51(45.5)$ \\
\hline Construction of animal shed & - & $42(37.5)$ & $70(62.4)$ \\
\hline Disposal of cattle wastes & - & $23(20.5)$ & $89(79.5)$ \\
\hline \multirow[t]{2}{*}{ Maintenance of farm and dairy records } & - & $5(4.5)$ & $107(95.5)$ \\
\hline & Involvement index $=8.24 \%$ & & \\
\hline \multicolumn{4}{|l|}{ Dairy processing activities } \\
\hline Processing of milk & $111(99.1)$ & $1(0.9)$ & - \\
\hline \multirow[t]{2}{*}{ Milking of animals } & $112(100)$ & - & - \\
\hline & Involvement index $=92.4 \%$ & & \\
\hline \multicolumn{4}{|l|}{ Health care activities } \\
\hline Vaccination/Medication & - & $40(35.7)$ & $72(64.3)$ \\
\hline Care of new-burns & - & $53(47.3)$ & $59(52.7)$ \\
\hline Care of sick animals & - & $55(49.1)$ & $57(50.9)$ \\
\hline \multirow[t]{2}{*}{ Taking calves for dehorning } & - & $4(3.6)$ & $108(96.4)$ \\
\hline & Involvement index $=10.41 \%$ & & \\
\hline \multicolumn{4}{|l|}{ Marketing activities } \\
\hline Selling of milk and milk products & $112(100)$ & - & - \\
\hline Purchasing cattle & - & $1(0.9)$ & $111(99.1)$ \\
\hline \multirow[t]{2}{*}{ Selling of cattle } & - & $3(2.7)$ & $109(97.3)$ \\
\hline & Involvement index $=93.24 \%$ & & \\
\hline
\end{tabular}

The result in Table 4 shows the overall involvement index of respondents. The result therefore revealed that majority $(91.1 \%)$ of the respondents were highly involved in dairy production activities, while few of the respondents $(8.9 \%)$ had low involvement in dairy production activities.

Table 4. Overall Involvement index of respondents

\begin{tabular}{llll}
\hline Categories & Index score (\%) & Frequency & Percentage \\
\hline Low & $0-33$ & 10 & 8.9 \\
High & $34-100$ & 102 & 91.1 \\
\hline
\end{tabular}

Table 5 shows factors influencing extent of involvement of respondents in dairy production activities. The result showed that income and secondary occupation were significant $(p<0.05)$ factors affecting extent of involvement of respondents in dairy production activities. The result further revealed that there were positive regression between marital status, income, household size, herd size, other livestock species raised by the respondents and their extent of involvement in dairy production. However, there was no significant effects $(p>0.05)$ of educational level, purpose of production, year of experience, breeds of cattle on extent of involvement of respondents in dairy production. The R2 was 0.317 indicating that about $31.7 \%$ of the extent of involvement of respondents in dairy production was explained by influence of their cattle production characteristics. 
Table 5. Factors influencing the extent of involvement of respondents to dairy production activities

\begin{tabular}{lllll}
\hline Variables & B & SE & t-value & p-value \\
\hline Marital status & 0.164 & 0.501 & 0.327 & 0.744 \\
Income & 0.717 & 0.313 & 2.289 & $0.024^{*}$ \\
Household size & 0.043 & 0.436 & -0.100 & 0.921 \\
Educational level & -0.527 & 0.389 & -1.355 & 0.179 \\
Secondary occupation & -0.981 & 0.379 & -2.419 & $0.017^{*}$ \\
Herd-size & 0.310 & 0.317 & 0.977 & 0.331 \\
Breeds of cattle & -1.255 & 0.811 & -1.548 & -0.125 \\
Source of animal & -0.981 & 3.495 & -0.281 & 0.780 \\
Year of experience & -0.949 & 0.551 & -1.722 & 0.088 \\
Other Livestock species & 0.079 & 0.161 & 0.489 & 0.626 \\
Purpose of production & -0.22 & 0.032 & -0.066 & 0.484 \\
\hline & $\mathrm{R}^{2}=0.317$ & & \\
\hline
\end{tabular}

\section{B - Regression coefficient; SE - Standard Error}

\section{Discussion}

Result on age of respondents agrees with the report of Popoola et al., (2017) that agriculture production is a profession that is practiced by people of different age groups both young, middle age, old people, and also an indication that most of the respondents were youth, who are capable of carrying out rigorous activities associated with dairy milk production. Majority of the respondents were married; this is expected with result obtained for their age. Married respondents are likely to be under pressure to produce more, not only for family consumption but also for sale. With the level of education of the respondents, this implies that majority of the respondents cannot read and write. Thus, this may hinder better communication as well as adoption of innovations Popoola et al., (2017) that educated farmers can easily understand and adopt new innovations and improved practice. The mean household size was 9. This result disagrees with result of previous studies Popoola et al., (2017); Odebode and Popoola, (2016); these authors reported 2-6 members as the modal family size among households. Differences in income of respondents could be related to number of cows possessed by them or their husbands (Table 1).

Result obtained for years of experience of women in dairy enterprise (Table 2) implies that respondents had enough experience in dairy production which helps efficiency and have a better understanding of the environment and marketing channels. Respondents in the study area possessed large number of cattle which may increase the milk yield of cattle and increased production. The fact that majority of the respondents inherited most of their cattle is an indication that cattle production is a means of lineage and succession business among the respondents who are largely pastoralists; that is, children take over cattle production enterprise from their parents. White Fulani breed of cattle is mostly raised among the respondents because of the fact that it is an indigenous cattle breed raised for dual purpose (milk and beef).

The result in Table 3 shows the extent of involvement of respondents in dairy production. The dairy production activities were classified into four sections which are the daily management activities, processing activities, healthcare activities, and marketing activities. The result revealed that there was low involvement of women in daily cattle management activities, this is due to the fact that the Fulani Pastoralists in Nigeria perceive cattle production activities such as grazing, cleaning of shed and the animals, feeding of the animals among others as duties of men folks while women were only restricted to milking and other activities related to milk processing. The result of this study disagrees with result of Veeranna and Singh (2004) who reported that women were highly involved in bringing of fodder and feeding concentrates for dairy cattle. The respondents were highly involved in milk processing activities. Involvement index of respondents for health care activities was $10.41 \%$ which implies they have low involvement in health care activities. This may be due to the fact that most health activities requires skills of trained personnel and external contacts and few of these activities are done by their male counterparts in the households. The result of this study disagrees with result of Sowjanya (2014) who reported high level of involvement of women in health activities of dairy cattle. Veeranna and Singh (2004) also reported that women play prominent roles in care of pregnant animal and calves. The result further, revealed that the level involvement of respondents in marketing activities of dairy production was high; an indication that bulk of marketing activities lie with women.

The overall involvement index of respondents (Table 4) was used as an indication of level of involvement of the women in dairy production activities. The index scores of Sowjanya (2014) was adopted which ranged and was 
scored as follows: index scores of range $0-33 \%$ (low involvement) and $34-100 \%$ (respondents were highly involved in activities). The overall involvement index showed that most respondents were highly involved in dairy production activities. Although women are restricted to some aspects of dairy cattle production activities such as grazing, housing and health care of these animals. This was due to beliefs, norms and tradition of the respondents who are Fulanis; their believe is that large animals like cattle can only be handled by men, thus such large animals are meant for men while small ruminant animals like sheep and goat as well as other livestock species like chicken, guinea fowl should be handled and are meant for women and children. The overall involvement index of the respondents was as a result of their involvement in major activities of dairy production which include milking of cattle, processing of milk, sales and marketing of milk and milk products

The result revealed positive regression coefficients for marital status, income, household size, herd size, other livestock species raised by the respondents. This implies that as the values of these variables (marital status, income, household size, herd size, other livestock species raised by the respondents) increase, the extent of involvement of women in dairy production increases. However, there was no significant effects $(\mathrm{p}>0.05)$ of educational level, purpose of production, year of experience, breeds of cattle on extent of involvement of respondents in dairy production. This implies that as these independent variables increases, the extent of involvement (dependent variable) tends to decrease. The R2 was 0.317 indicating that about $31.7 \%$ of the extent of involvement of respondents in dairy production was explained by influence of their cattle production characteristics.

\section{Conclusion}

Based on the result of the study, it was concluded that most of the respondents were highly involved in processing and marketing of dairy product; they were not involved in daily management and health activities. It was further concluded that the overall involvement index of the respondents was high in dairy production enterprise. Income and secondary occupation were significant factors influencing extent of involvement in dairy production enterprise. considering the result obtained in this study, an effective marketing channel should be developed to ensure fair price of milk and other dairy products for the women, this will increase share in self-employment and income generation. Also, there is need for enhancing value addition on milk and milk products particularly for women who are involved in the enterprise through education and training on emerging technologies in dairy farming.

\section{References}

Garcia, O., Mahmood, K., \& Hemme, T. (2003). A review of Milk Production in Pakistan with Particular Emphasis on Small-Scale Producers" Pro-Poor Livestock Policy Initiative. PPLPI Working Paper No. 3, International Farm Comparison Network IFCN, FAL.

Gour, A. K. (2002). Factors influencing adoption of some improved animal husbandry practices of dairy farming in Anand and Vadodora districts of Gujarat state, Ph.D.Thesis. Gujarat Agricultural university, SK, Nagar. Gujarat (India).

Khin, M. O. (2005). Knowledge and adoption of Improved dairy management practices by women dairy farmers in Dhaward district. M.Sc, Thesis,univ. Agric. Sci,Dhaward Karnataka (India).

Kristjanson, P., Waters-Bayer, A., Johnson, N., Tipilda, A., Njuki, J., \& Baltenweck, I. (2010). Livestock and Women's Livelihoods: A Review of the Recent Evidence. ILRI Discussion Paper No. 20. Nairobi.

National Population Commission. (NPC). Nigeria 2006. Census Report.

Odebode S. O., \& Popoola, M. A. (2016). Comparative analysis of income generation from sheabutter production by rural women in Saki West and ATISBO Local Government Areas, Oyo state, Nigeria. Science and Engineering Perspectives, 11, 71-83.

Popoola, M. A., Adebisi, G. L., Osijinrin, O. E., Babarinde, G. T., Lawal, A. M., \& Kunuji, O. M. (2017). Determinant of backyard poultry production as strategy for food security among households in Ibadan Metropolis. Nigeria. Proceeding of 6th ASANNLAS Joint Annual Meeting. September 10-14, 2017. Abuja.

Rubin, D., \& Missokia, E. (2006). Gender audit/Tanzania. United States Agency for International Development. Washington DC. 53pp.

Savitha S. S. (2004). Role of rural women in animal husbandry. M.Sc (Agri.) Thesis, univ, Agric Sci, Dhaward, Karnataka (India).

Sethi, N. (2013). Factors Affecting adoption of scientific technologies by dairy women. Proc. of international dairy conference, 2, 166-167.

Sowjanya, S. (2014). Management efficiency of dairy farm women. M.Sc Thesis University of Agricultural 
Sciences, Dharwad, 33-101.

Tibi, K. N., \& Aphunu, A. (2010). Analysis of Cattle Market in Delta State: The Supply Determinants. African Journal of General Agriculture, 6(4), 199-203.

Veeranna, K. C., \& Singh, D. P. (2004). Gender analysis of dairy and crop production system in Bider district of Karnataka, Karnataka. J.Agric.sci, 17(2), 32-36.

Wadear, P. R., Kiresur, V. R., \& Gaddi G. M. (2003). Human labour absorption in dairy farming in Karnataka. An Economic analysis, Rural India, 66(12), 243-247.

\section{Copyrights}

Copyright for this article is retained by the author(s), with first publication rights granted to the journal.

This is an open-access article distributed under the terms and conditions of the Creative Commons Attribution license (http://creativecommons.org/licenses/by/4.0/). 